\title{
LA POÉTICA DE FRANCISCO MADARIAGA: Su Intertextualidad
}

Sylvia Lesa

\section{"Tout texte se construit comme mosaïque de citations, tout texte est absoption et transformation d'un autre texte. JULIA KRISTEVA}

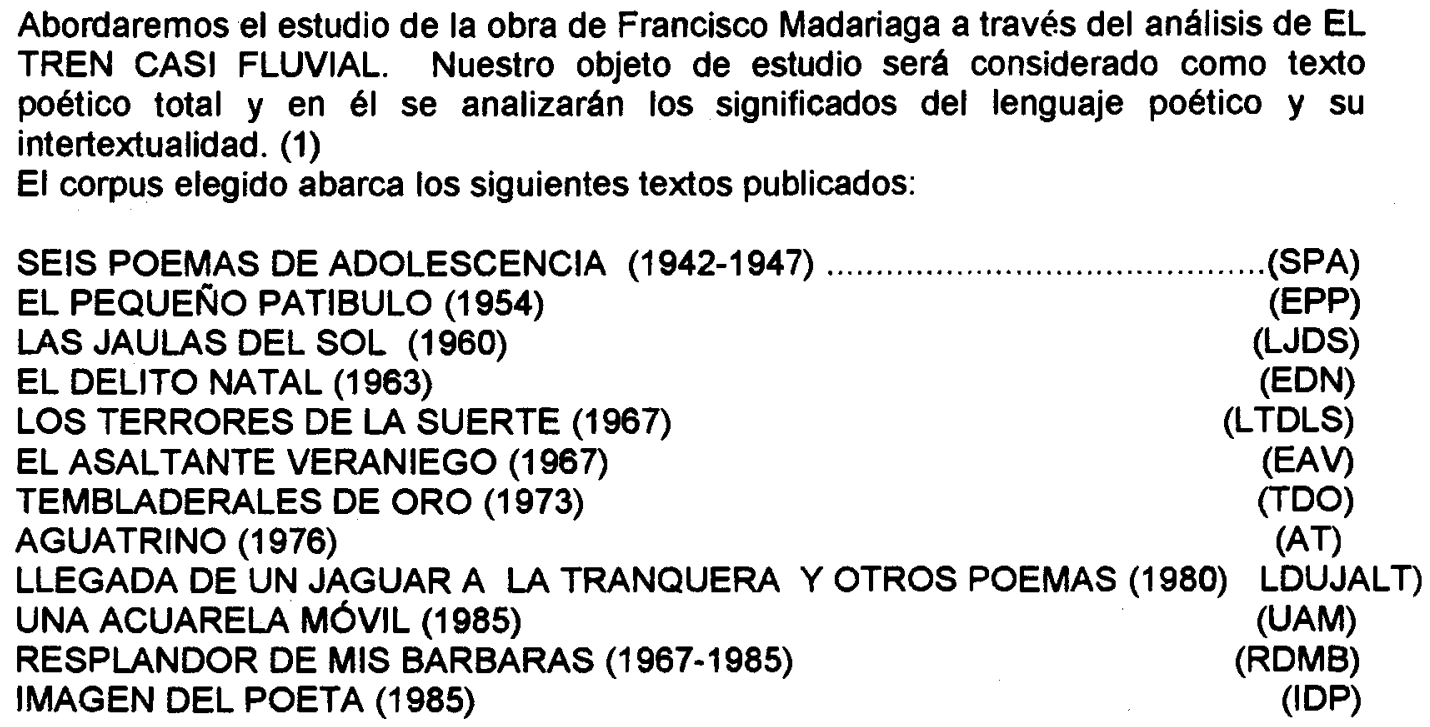
TREN CASI FLUVIAL. Nuestro objeto de estudio será considerado como texto poético total y en él se analizarán los significados del lenguaje poético y su intertextualidad. (1)

El corpus elegido abarca los siguientes textos publicados:

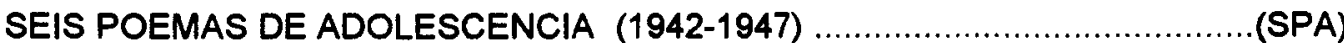

EL PEQUEÑO PATIBULO (1954)

LAS JAULAS DEL SOL (1960)

EL DELITO NATAL (1963)

LOS TERRORES DE LA SUERTE (1967) (LTDLS)

EL ASALTANTE VERANIEGO (1967) (EAV)

TEMBLADERALES DE ORO (1973) (TDO)

AGUATRINO (1976)

LLEGADA DE UN JAGUAR A LA TRANQUERA Y OTROS POEMAS (1980) LDUJALT)

UNA ACUARELA MÓVIL (1985) (UAM)

RESPLANDOR DE MIS BARBARAS (1967-1985) （RDMB)

IMAGEN DEL POETA (1985)

Francisco Madariaga, nacido en 1927, publica su primer libro (EPP) EN 1954; la mayor parte de su producción se encuentra comprendida entre las décadas de los 60 a los 80 .

Habiendo vivido hasta los catorce años en Corrientes (experiencia que marcará definitivamente su poética) reside desde entonces en Buenos Aires pero sin haber perdido jamás el contacto con la tierra de su infancia ("siempre he vuelto y volveré a esa República Natural y Joyante"...) (2)

Dentro de la poesía de los años 60, Madariaga se encuentra inscripto en la línea de la experimentación vanguardista, aquella que "trabaja con el discurso poético y se vuelve reflexión sobre sus mismas condiciones de producción (cuyo intertexto más evidente son los poetas franceses de la modernidad: Mallarmé y Rimbaud, junto con el movimiento superrealista)" (3) 
Esta preocupación por el acto creador está manifiesta en las numerosas Artes Poéticas presentes en el texto, así como en otros poemas donde Madariaga configura su concepción poética:

"Con un don infernal de encanto y de sonido/loras entre los hombres tu desacuerdo/con el lenguaje" (Cenit con reportaje; EPP)

"Tú no te recuestes más acá de los lenguajes humanos" (Arte poética, LJDS)

"La poesia es la tenaza de adiestración fulminea (...) Tenaza de anti-realidad sangrante, de anti-alienación del Trabajo y del ocio esclavizantes y deformantes, manejada desde el infierno por la bruja celeste y cálida de la esperanza." (Arte poética príncipe y pirata; EAV)

" $Y$ un poeta es aquél que vuelve siempre desesperado y hambriento a los poemas, a sus poemas con un rostro feroz de desterrado y de enamorado: el gesto más humanisimo y más sombrio, al mismo tiempo. (...) Siempre del lado de la rebelión: lúcido y tiernísimo frente a ios más infelices; duro, exacto, cruel, frente a los imbéciles de los grandes poderes." (idem cita ant.)

En los ejemplos citados, la poesía es sentida como marginalidad frente al lenguaje y a la realidad. Es pasión y es destierro. Pero también es compromiso, rebelión y esperanza.

La adhesión a los postulados de la vanguardia (específicamente al surrealismo) es innegable.

Alguna vez, Madariaga explicaría que en el surrealismo encontró no una modalidad escritural sino "una dirección del espíritu" a la que permanecería fiel (rebelión, apertura de los sentidos, libertad incondicional). (4). Sin embargo, en un cuestionario realizado para la Fundación Argentina para la Poesía, al preguntársele si se considera integrado a una generación, escuela o movimiento poético, el poeta responde: "¿Acaso todo poeta no quisiera responder con aquella afirmación de Rubén Darío "Mi poesia es mia en mi?"

Sin que ella limite la conciencia de todo lo que le debemos a los poetas de todos los tiempos. ¿Escuelas, academias, capillas literarias? No..."

Su poética desbordará los postulados teóricos de la vanguardia (aún cuando siga utilizando sus recursos técnicos) y su lenguaje se hará más personal, sumergiéndose en la Naturaleza y en el paisaje de Corrientes como una forma de reparación de su exilio interior.

"Un poeta debe cantar y nada más. Y cuando tenga/ que elegir "entre la nada y la pena" eligirá la rojal y fulgurante movilidad de la poesía". (Arte poética príncipe y pirata; EAV)

"No puedo con el vicio feroz de la poesía, de la naturaleza". (Aparición duerme; EDN)

"Yo escribo porque me alza la naturaleza": (Idem) 
"Yo escribo porque me alza la naturaleza": (Idem)

"Se es poeta por una amplia sonrisa de las aguas". (Arte poética principe...)

"Me interesan los poetas que lo son por indicación de las lejanisimas razas-madres de la naturaleza" (Carta a poetas, mercaderes y pseudo aristócratas de nuestro tiempo; LTDLS)

Pero Madariaga, en su preocupación por la creación del texto poético, arriba a un camino sin retomo: la anulación de toda teoría acerca de la creación. En su último libro (RDMB), confiesa no haber podido resolver un proyecto poético definitivo:

"Después de esto, comprenderéis que no puedo decretar /definitivamente/ninguna Poética?".(El Paraíso del estero)

A la par de estas búsquedas de un lenguaje personal y autárquico, en su poética siguen presentes muchas caracteristicas propias de la vanguardia:

\section{a.-Aire profético en la enunciación del lenguaje:}

"Debe mantenerse bien montado, (...) hasta el día de La Ultima Coronación: la de la hermandad, cuando, junto a un Gran Fogón al ras del suelo, se arreglen las cuentas con la Vida a nivel del horizonte". (Llegada de un jaguar a la tranquera).

\section{b.-Conciencia de su misión como poeta:}

"es necesario llevar la/misión cumplida: /Ser criollos hasta la Ultima/Coronación de la hermandad. (Canción de tigres- EI bosque junto al mar; AT)

"Otra de las misiones del poeta: desprender y / ahuyentar a los muelles flotantes, cargados de mercaderias de la peste, del desprecio, de la iniquidad, que flotan junto a los puertos/ de las grandes capitales del infierno social". (Imagen del poeta).

c.- Sentir que el poema, el texto, es dictado desde afuera, por extrañas fuerzas que contribuyen a su creación:

"A veces, recibo indicaciones -muy rápidas- de una jinetería armada (...) Son las ánimas de los antiguos guerreros, bandoleros, troperos (...) que me ordenan proyectar todas las imágenes que yo haya recibido de esos móviles pedazos de recuadros del mundo". (Apariciones, UAM)

Madariaga dirá en una entrevista: (5) 
"-Ahi es donde yo soy religioso (...) Esa religiosidad para mí consiste en cómo se me imponia la imagen. No puede ser no religiosa la forma de imponerse (...) Para mí la poesía llega ya resuelta y se proyecta, nada más...".

\section{d.- Utilización de los recursos técnicos propios de la estética surrealista:}

\section{AUTOMATISMO:}

"En la aurora de los niños aprendimos a cosernos la boca con un gran retrato con manos de nuestra alma y un trago del aliento de las bestias que hoy nos hace rechazar los paraísos del orden y el templo de las leyes con encanto y zurdo ronroneo de gato totalmente estirado hacia la sombra, vomitando seda y balas". (Almuerzo y gato onza, LJDS)

\section{ILOGICIDAD:}

"cuando ya se ha cruzado en la memoria el pequeño/patíbulo vibrando para la suerte de onza /de odio del encaminado". (EI pequeño patíbulo, EPP)

"A su labor de vendedor de bananas a la orilla/ del rio diario de azúcar de $\mid$ sífilis de/ sonido. "(Amanecer fluvial, EPP)

\section{IMAGENES QUE LLEGAN AL ABSURDO:}

transforma."

"Las cosas tienen un mulato carnero que las araña y las

"Tienen un santo salido de un pantano que nos ahorca en los amaneceres de la sed." ( La boca del mundo; LJDS)

"Yo tengo una bolsa de fuego cautivado por los gatos monteses pegada sobre el labio": (Las jaulas del sol)

"hija de los caballos, que/ arrancas los limones por la noche con tu muñeca de sífilis golpeada por el rey del estero": (Tormenta y servidumbre, LJDS)

\section{ASOCIACIONES FONETICAS (Libertad de imaginación)}

"Cercando el/camposanto de los hombres del hambre"(Cementerio amarillo al borde del agua, TDO)

"a hacer comercio de almas, de armas (Llegada de un jaguar...)

impopular, TDO)

"y que sólo saluda a la sombra con sombrero"(El canto 
impopular, TDO)

"y que sólo saluda a la sombra con sombrero"(El canto

"correos del zar-azar"(La balsa mariposa)

\section{ENUMERACIONES:}

"No soy el espectral, ni el sangriento, ni el cautivo, ni el libre ni el trompudo de labios de lata, ni el acordeón del mal-ayer, ni la blancura del futuro, ni el bobalicón del espacio, ni la academia de los astros, ni el planetario de las correspondencias": (Nueva Arte Poética; EDN

"La vanguardia desmantela el discurso instaurado, 10 convierte en un transcurso de desarrollo imprevisible que conecta por relaciones aleatorias los componentes más disímiles; vuelve al poema excéntrico, polimorfo, politonal, multívoco. instaura la posible ruptura de todos los continuos: lógico, rítmico, temporal, espacial, causal, lingüístico, ruptura de los criterios de semejanza y diferenciación, de los de clasificación y jerarquización; ruptura de todas las permanencias (...)lo absurdo, lo arbitrario, la fealdad agresiva, lo prosaico, lo demoníaco, lo instintivo, lo demencial, 10 onírico, todo ingresa a la pululante poesía de vanguardia, partícipe de un mundo que acrecienta sus contradicciones. "(6)

Madariaga comete una transgresión (7) más:

a-*Inventa nuevos vocablos, dotándolos de una significación personal, creando así nuevos semas:

valientero, ferozteador, feroztea, alumbral, maullación, unílico, sangrarada, alarilear.

b-*Combina dos o más semas entre sí otorgándoles un nuevo significado: (8)

Contraamparo; Aguatrino; innemociones; Elmalgarzal; entresobresí; trascoloreado; co-alumbré.

\section{C-*Dota de nueva significación a palabras (o semas) existentes:}

Trino, Ras, Tigre

d-“Crea nuevas estructuras sémicas: (9)

el hada-yegua de los manantiales

brujas-blancas-ruanas

Jaguar-Jinete 
una mañana Ley-País del Día Puro

e*Subvierte estructuras sintácticas:

se levanta todo el polvo/ del fuego de las mis entrañas

\section{EL CONCEPTO DE INTERTEXTUALIDAD:}

Para Kristeva "el texto es una productividad, lo que quiere decir: a) que su relación con la lengua en la que se sitúa es redistributiva (destructivo-constructiva), y por consiguiente resulta abordable a través de las categorías lógicas más que puramente lingüisticas, b) que es permutación de textos, una intertextualidad: en el espacio de un texto varios enunciados, tomados a otros textos, se cruzan y se neutralizan": (10) "El lenguaje poético aparece como un diálogo de textos: toda secuencia se hace con relación a otra que proviene de otro corpus, de tal suerte que toda secuencia está doblemente orientada: hacia el acto de la reminiscencia (evocación de otra escritura) y hacia el acto de la intimación (la transformación de esa escritura)(11).

"Se crea asi en tomo al significado poético, un espacio textual múltiple cuyos elementos son susceptibles de ser aplicados en el texto poético concreto. Denominaremos a este espacio intertextual. (12)

Distinguimos tres modalidades de intertextualidad:

\section{1-INTERTEXTUALIDAD DE PRIMER GRADO (Intertextualidad con otros autores)}

a) El texto ajeno como cita

b) El texto ajeno como reminiscencia

\section{2-INTERTEXTUALIDAD DE SEGUNDO GRADO (Autocita):}

Cita de un texto de otra obra del autor

\section{3-INTERTEXTUALIDAD DE TERCER GRADO (Autocita):}

Cita de otra parte del mismo texto

Por razones metodológicas, abordaremos primeramente la Intertextualidad de Segundo y de Tercer Grado. En una etapa posterior analizaremos la Intertextualidad de Primer Grado, con otros autores de vanguardia o con autores pertenecientes a la misma generación que Madariaga.

\section{LOS METALENGUAJES: FRANCISCO MADARIAGA $Y$ SU AUTO- INTERTEXTUALIDAD:}


En el texto, la Intertextualidad se articula a través de dos niveles:

-Nivel mítico o simbólico: semas o sememas (conjuntos significativos) que representan temas recurrentes

-Nivel lingüístico:

${ }^{\star}$ Repetición de semas inventados o re-construidos

"Repetición de sememas idénticos

"Construcción de estructuras sémicas (sememas) similares

Ambos niveles pueden darse:

"Dentro de un mismo texto

"Dentro de dos o más textos de la obra

Dentro del primer nivel, comenzaremos a analizar el texto desde el título: EL TREN CASI FLUVIAL; construcción sémica formada por semas que se han contaminado mutuamente, dando origen a un nuevo sema con la significación de viaje acuático.

El título se encuentra relacionado con el texto total y con cada uno de los textos parciales existentes dentro de él. Además es también el título de una de las prosas poéticas del libro Llegada de un jaguar a la tranquera, prosa que sintetiza la biografía y los grandes temas de la poética de Madariaga. Es éste, por lo tanto, un título abarcador y sugeridor de significados.

La obra reunida es un extenso poema-viaje circular hacia el paisaje natal, hacia el pasado y hacia el interior del yo-poético y existencial.

Tres tipos de transportes son abordados en el texto:

*el tren

*Ios transportes acuáticos

* los transportes terrestres antiguos

(los transportes ciudadanos aparecen en el texto pero no recurrentemente)

El sema tren significa el viaje y es uno de los vehículos utilizados por la memoria para volver una y otra vez al origen.

Cuando el yo arriba al paisaje natal, los semas utilizados son otros: Balsas, canoas, vapores y también carretas, volantas, carruajes, berlinas (vehículos del pasado). Otra constante dentro del texto es la presencia de los semas viajero, pasajero, turista.

Pero el texto es también un poema-río, caudaloso, rico, abarcador de imágenes, impetuoso, un río que avanza y retrocede, devorando ciclos, ampliándose cada vez más en busca de la memoria convocante; un río que se repite continuamente a si mismo, reiterando temas, recursos, estructuras, para poder representar el litoral actual continuamente buscado.

La presencia del sema agua es una constante, un eje temático (la memoria lleva hacia el agua, el agua convoca a la memoria). Encontramos el agua en todas las 
"más acá" en el tiempo y en el espacio: el agua oceánica, la presencia del mar como compensador. Semas: mar, océano.

La poética de Madariaga es, además de acuática, una poética de los Elementos de la tierra, el fuego, el aire. El sema tierra es un elemento reparador (al igual que el agua) e integrador: a través de la tierra, el yo poético se integró al cosmos. El sema tierra está presente como tai o con semas como paisaje, paraje, el Paraje, Paisaje-Paraje, el Cosmos Correntino, la Comarca, el País, el País Correntino, la República Natural y Joyante, el esteral guarani- correntino.

La tierra abarca dentro de sí a lo vegetai (Semas: bosque, juncal, caña, irupé, tacuaral, palmera y sus variantes: palmar, palmeral, palmerales, palmas) (13) y animales autóctonos (Semas: loro, garza, jaguar, yacaré, mono, tero, gato montés).

En los primeros libros, el paisaje es más bien tropical (Semas: selva, cocoteros, bananos, plátanos) y relacionado con lo maravilloso.

En toda la obra, el paisaje es frecuentemente transformado por mecanismos surrealistas o re-creado a partir de la memoria. El Paisaje Natal es sentido como lo natural-primigenio ("Sueño natal universal del Cosmos Correntino).

\section{OTROS SEMAS RECURRENTES EN LA OBRA:}

* La sangre y las degollaciones: casi siempre utilizado con el significado negativo de "ir desangrándose", de muerte cruenta y dolorosa.

("me sangra la poesia por la boca"/" vuelve a sangrarme la poesia por la boca", "memoria sangral", "Utopía sangrante", "ese tambor de sangre es tu país", "sangrante balsa", "las degollaciones de sangre es tu pais", "sangrante balsa", "las degollaciones esterales", "sangrias flotantes de degollaciones").

*Los colores: presentes en numerosas imágenes visuales. Se destacan:

"el color verde: (de la vegetación)

"el color oro: ("tembladerales de oro")

*el color rojo: (del fuego y de la sangre)

*el color del paisaje: tiene los colores de los partidos políticos correntinos

("llanura gateada celeste, colorada, verde" "palmeras celestes, coloradas, verdes" "cruces celestes, coloradas, verdes, negras")

"Lo maravilloso: brujas, hadas ("brujas blancas", "hadas del palmeral", "hadas primitivas", "hada sexual de la naturaleza").

*Antepasados, fantasmas y apariciones: como una forma de vencer al tiempo. "La vanguardia también acentuará su futuridad de un modo contrario en apariencia: legitimando su actualidad con la recreación de un pasado, adelantándose a su constitución como memoria cultural. Así aparece el tema de los antepasados, los mayores, los linaies, los fundadores." (14) 


\begin{abstract}
*Antepasados, fantasmas y apariciones: como una forma de vencer al tiempo. "La vanguardia también acentuará su futuridad de un modo contrario en apariencia: legitimando su actualidad con la recreación de un pasado, adelantándose a su constitución como memoria cultural. Así aparece el tema de los antepasados, los mayores, los linajes, los fundadores." (14)
\end{abstract}

( "ánimas", "la luz del padre al otro/extremo del poder y la delicadeza"; "Fantasmas del poder y de la delicadeza", "apariciones")

"Criollismo: "Uno de los procedimientos de la vanguardia es apropiarse del criollismo, reformulándolo desde una nueva estética donde varie su función y fundando un espacio mítico-poético privilegiado donde la nacionalidad se encarne "naturalmente". (15)

"es necesario llevar la/misión cumplida ser criollos hasta la Ultima/Coronación de la hermandad" (El bosque junto al mar, AT)

Presencia del criollo, del gaucho, del mestizo, la "raza gaucha","beduino-gauchi-afrohispano-guaraní", "viejecillas gauchi- indias", "viejecillas gauchi-afro-guaraníes".

Lo criollo es re-creado, pasado por el tamiz de la memoria, utilizado como catarsis (como fuga de la realidad urbana), paisaje y personajes son transformados, reconstruidos, cargados de significados personales. Apropiarse del lenguaje criollo (gaucho, flete, ruano, chasqui, apero, yeguarizo) y

guaraní (yaguareté, yaguané, Arazá-tí) para incorporarlos al lenguaje poético, es apropiarse de la tierra y de su gente.

*Naturaleza-Ciudad: "Desde el comienzo aparece y persiste el antagonismo conflictual entre un presente precario impulsado coercitivamente hacia un futuro incierto y la nostalgia de la presencia constante y total, de la completud, de lo axial, de lo numinoso, conflicto entre un hábitat manufacturado, unificado por la estandarización a escala mundial y el deseo de regresión al orden protector, al orbe maternal, al mundo mítico, conflicto entre la movilidad alucinatoria de la era de las comunicaciones y el asentamiento reparador de la autoctonía, de lo solariego, de lo natal". (16)

Semas: "alba cálida", "alba guaraní" (semas reparadores)

Dijimos anteriormente que en el nivel linqüistico, la intertextualidad se presenta en:

-Repetición de semas inventados o re-construidos:

Elmalgarza-real, feroztear, Aguatrino, Trinos 
-Construcción de estructuras sémicas (sememas similares):

Delito Natal/ Hechizo Natal

el alba cálida/ el alba guarani

con boca de serpiente canta/ la boca verbal de la serpiente

paraísos de penal infantil/ infantilismo penal

Podemos encontrar estos semas recurrentes en varios textos de la obra reunida(intertextualidad de segundo grado) o en textos de una misma obra (intertextualidad de tercer grado).

Ejemplo de intertextualidad dentro de un mismo texto es llegada de un. jaguar a la Tranquera y otros poemas. En este texto, el autor desarrolla los mismos temas en poemas y en prosas poéticas. Prosas y poemas llevan los mismos títulos y, textos similares por su tema y significación, son permanentemente confrontados entre sí a través de la utilización del mismo lenguaje: construcciones sémicas idénticas o presencia de los mismos semas escriturales.

"hoy vuelco sobre ti mi corazón, con/ Miguelito, tu bello niño de once años y largas trenzas/, ahogado en la laguna y el paisaje".

(Escritorio criollo y niño ahogado)

"¿Me entiendes, /cuando cantan los cabellos de oro de tu/ahogado Miguelito, /en la laguna secreta del cantar?"(id)

"ciervo que olfateas tesoros"/ "Un ciervo que olfatea un tesoro"

"El Tesoro del Olor del Infinito"/ "el puente del olor del infinito" / "la Pasarela para el Tigre de los Sueños" (Puente Florencia)

"...tú, el errante doctor gaucho, / el emponchado sobre el antiguo bayo ruano, el Caballero de los Trinos, mi padre, me traes ahora un Trino Blanco para desterrar de mi corazón al Trino Negro" (El bayo ruano)

"...volviendo, / con el fuego, / el aire de alguien, /¿para mí?/ montado sobre el antiguo bayo ruano del/ emponchado/para la restitución del Trino Blanco en el/ corazón del Trino Negro" (id)

LDUJALT contiene también la prosa poética "El tren casi fluvial", prosa abarcadora y sintetizadora de temas desarrollados en otros libros, contiene en sí construcciones sémicas que se repiten en otros textos: 
memoria fulgurante y sangral; Jefes Criollos; Jefes Naturales; tren antiguo, marrón, casi fluvial; hadas del palmeral, Ras de la Naturaleza correntina; Sueño Natal Universal del Cosmos Correntino; en trenes, en balsas, en carretas, en canoas; un chasqui de guerra y otro colorado.

Otros semas frecuentemente intertextuales en toda la obra: Paisaje; Paraje; Pais Correntino; el Cosmos Correntino; La Ultima Coronación: la de la hermandad; Gran Fogón.

El poema La Balsa Mariposa (Otros Poemas) es también un buen ejemplo de intertextualidad de segundo grado: Sangrante balsa mariposa; Balsa de brujas blancas; sombras negras, celestes, coloradas, verdes; mulatas verdes de ojos dorados; pobrísimas viejecillas gauchi-indias; salvaje palmeral del borde del estero; salvaje orilla del estero; tembladeral de los secretos; país natal; palmeral acuático.

En Una Acuarela Móvil, el poema que da título al libro y las prosas posteriores (Apariciones; Palmeras en el Agua; Trinos Blancos o Negros) son ejemplos elocuentes de intertextualidad con el resto de la obra: primitivo gauchillaje; arenas de oro anaranjado; sangrias flotantes de degollaciones.

"Apariciones": arenas del color de las sangres asesinadas o históricas; tembladerales; palmerales; esterales; cazadores de malayas facciones; mulatas verdes de ojos dorados; rigurosa mulata... que cuida de una doncella especial de párpados arcangélicos; sangre del palmeral; antiguo y ancestral estero.

."Palmeras en el Agua": móvil poesía de las aguas y los colores; las pasiones, los pactos secretos o a pleno sol, Animita viva de su cosmos; Reino Natural; sangrante resplandor; esteros milenarios y ardientes; mis caballos de muy veloces oros sanguineos.

."Trinos Blancos o Negros": ; la poesía es una isla; Lago Nacional del Infinito; trinos blancos o negros de la suerte

Resplandor de mis Bárbaras (1967-1985): es el último de los libros contenidos en EL TREN CASI FLUVIAL. EI mismo es una síntesis de los textos que lo preceden. Presenta una intertextualidad constante con los demás textos: contiene semas presentes en toda la obra: hechizo natal; vuelve a sangrarme la poesía por la boca; bruja blanca; potrillo de oro siempre sanguíneo; degollaciones esterales; Palmar; Parajes y desparajes; PAISAJE. Podemos considerarlo como un texto engiobante y terminal, un libro no sólo de sintesis de la obra anterior sino también de síntesis existencial; un libro donde se confiesa no haber podido resolver un proyecto poético definitivo: "¿comprenderéis que no pueda decretar, definitivamente, I ninguna Poética?" (EI paraíso del estero) ni tampoco los grandes conflictos existenciales personales: 
"No podré salir nunca del hechizo natal/ hasta no haber terminado con las cóleras/ y los resplandores de los asesinatos/ y las miserias artificiales del/ desamparo, I reverberando en los paisajes aún más que naturales.

Si no logro quebrar estas desnutriciones (...) que no me entierren bajo las brillantes/ navegaciones-alteraciones de este/ paisaje: / que me recuesten en el lejano este uruguayo..." (Palmares Colorados)

Es éste el libro de la caída, de lo terminal de la existencia, son frecuentes los semas referidos a la muerte (personal y de los otros): ataúd de oro; degüello; degollaciones; entierro; cementerio; agua de oro de la muerte.

Queda el interrogante acerca de si Resplandor de mis Bárbaras ha sido generador de otros textos de la obra o ha sido generado por ellos.

El análisis del texto estudiado nos permite concluir que la estrategia textual (17) utilizada por el autor será la intertextualidad. A través de ella, el lector volverá una y otra vez sobre la obra en sí, sobre sus temas, sus obsesiones y su lenguaje hasta alcanzar el origen, el cosmos personal del autor.

La intertextualidad es fundamental en este volver a través de la memoria, el pasado y el paisaje de Corrientes porque, al igual que la memoria que se repite a sí misma continuamente, el lenguaje deberá plagiarse para aprehender definitivamente el paraíso perdido, a la recurrencia de la memoria corresponde, en el plano textual, la recurrencia del lenguaje.

EI Lector modelo deberá ser un lector intelectualmente competente ("Oh mis pequeños seres del desamparo, canto/ mi canto con un lenguaje impopular, pero cercano / a vuestros vestidos miserables". El Canto Impopular; TDO), conocedor de los recursos de la vanguardia, dispuesto a dejarse seducir por el lenguaje, capaz de interpretar los significados enmascarados y audaz para acompañar al autor en su travesía a través de la memoria.

\section{RELACION ENTRE LAS OBRAS DEL AUTOR A tRAVES DE sEMAS INTERTEXTUALES:}

En los primeros libros de Madariaga (EI Pequeño Patíbulo, 1954; Las Jaulas del sol, 1960) se observa su adhesión a las técnicas surrealistas como gran preocupación estética ("cuando empecé a publicar había recibido ya el primer golpe del surrealismo"). (18)

Esta preocupación por la búsqueda de un lenguaje personal y la incorporación del mismo dentro del marco de la vanguardia elegida como opción, es puesta de manifiesto en el texto poético: "Con un don infernal de encanto y de sonido/ lloras entre los hombres tu desacuerdo /con el lenguaje" (Cenit con reportaje, EPP), "Tú no te recuestes más acá de los lenguajes/humanos"(Arte poética, LJDS).

En los dos libros mencionados están presentes semas recurrentes como: TREN, VIAJE, PASAJERO, AGUA, MEMORIA. A través de este último se produce el cruce psicológico hacia el pasado-paisaje. ("Cuando ya se ha cruzado en la memoria el pequeño patíbulo vibrando para la suerte de onza de odio del encaminadon(EPP)). 
En los primeros textos, Corrientes es nombrado de forma indirecta, se to sugiere mediante semas como "Tierra suspendida en la tela del agua y del fuego"(EPP),

"aquél paisaje de cristal desprendido del fuego" (EPP); "la tierra de la salvación y el infinito"(LJDS); "el alba cálida" (LJDS).

En la entrevista que le realizáramos, el poeta dice": En mi infancia, cuando yo me fui de Corrientes, estaba totalmente en contra del paisaje, del criollismo, incluso de la figura de mi padre que encarnaba justamente todo eso, y cuando yo tuve mi primer contacto con el surrealismo, con todo ese tipo de rebeldia, desde luego que no podía asimilarme a esa imagen, era fatal que lo hiciera, cuando esa experiencia culminó, tuve un rescate de la figura de mi padre. $Y$ con eso vino el paisaje (...) hubo un reconocimiento de cántico". (19)

Consideramos que en esta primera etapa de la obra de Madariaga es más importante la preocupación estética por el lenguaje, por la incorporación y utilización de nuevas herramientas, ("creo que esas herramientas que yo conquisté eran para ese paisaje")(20) que la aprehensión definitiva en el texto poético, de un paisaje que todavia no se encontraba conscientemente asumido, a pesar de la presencia de semas propios que se filtran una y otra vez en la red textual.

El siguiente libro, El Delito Natal (1963), muestra ya desde la dedicatoria ("A los bosques, a las aguas, a los hombres más desamparados del Pais Correntino"), un empleo de semas o conjuntos sémicos que nombran directamente al paisaje natal.

Lo que antes fuera aludido, se transforma aqui en mención directa de aquello de 10 que se está hablando. Hay, como dijera el poeta en la entrevista, un "reconocimiento de cántico".

"tierras paradas en aguardiente correntino" (Carta de enero)

"los labios del verano guaraní" (Arte natal)

Es en ese texto donde comienza a hacerse presente el tema de los fantasmas y apariciones, que se corporizan en la memoria y se transfieren al texto poético:

"ny la noche, cuando el agua desembarca todas las apariciones" (Apariciones)

*"Fantasmas del poder y de la delicadeza" (Aparición duerme)

*"ante la pura Aparición, soy tu dador sangrado en el encanto" (id)

El sema AGUA y el sema NATAL se ven repetidos en el texto:

*"El agua exorbitante está en mi boca" (Apariciones)

*"soy el aguador natal, soy el ferozteador natal" (Arte natal) 
A pesar de sentirse "cautivo del estero" (Apariciones), el poeta expresa:"Yo no quiero cantar paises natales, sino medallas de carne de sol, telas de la naturaleza"(Carta de enero), resistiéndose a ser apresado por un paisaje particular, que lo aleje de la universalidad.

Los Terrores de la Suerte (1967), indica ya desde el epigrafe, una continuación de ios temas anteriores: "Con vosotros, fantasmas, nunca tengo reservas y de vuestros remordimientos tengo lleno el corazón. Cuando es de día. Ungaretti":

Están también dentro del texto los semas referidos al AGUA (agua litoral: lagunas, esteros y el mar), la MEMORIA y lo NATAL pero este último con variaciones ("cargo antinatal", "paisaje no-natal". A través de los semas utilizados se hace lugar a la gran contradicción entre paisaje natal (Corrientes)-paisaje no natal (metrópoli: Buenos Aires).

En LTDLS, el poeta habla de "el reinado de los terrores de la poesia" (Carta a poetas...), el mismo tema, la preocupación por la poesía, la función poética y lo poético como maravillosos, es continuado en el siguiente texto (EI Asaltante Veraniego, 1967), abordado desde el epígrafe de Benjamín Péret:"Lo maravilloso no se fabrica por ninguna receta farmacéutica. Lo maravilloso lo agarra a uno por la garganta".

Este libro está compuesto únicamente de un ARTE POETICA PRINCIPE Y PIRATA donde se sintetiza la concepción poética de Madariaga:

"La poesía| es rebelión" (postura heredada del surrealismo), pero también

"se es poeta por una amplia sonrisa de las aguas"

La poesía es un rayo solar con todos los poderes de la tierra, del agua y del fuego, unificados" y es la "tenaza-porción de agua y de fuego unificados en el relámpago".

Madariaga asume en el discurso poético que su poesia debe aunar el fuego de la gran pasión por la literatura y los maestros (Rimbaud, Lautreamont, Apollinaire, los surrealistas) y el agua del paisaje natal unificándolos en el relámpago de la inspiración.

Lograda la síntesis entre la poesia vanguardista y el paisaje, incorporado este último al texto a través de la memoria, el siguiente paso será la incorporación de la gente habitante del pais correntino. Tembladerales de Oro (1973) está dedicado "para el recuerdo de Los Gauchos más Huraños; de mi abuelo, Narciso Madariaga, y de su amigo Aparicio Altamirano, salteador bandolero correntino, todos en el lujoso Palmar." Los semas que designan al paisaje estarán en este libro con los semas que se refieren a la gente, a los criollos o mulatos del lugar:

"vuelve los ojos al paisaje metido dentro de la carne y del fuego del movimiento humano más real el de los pasitos de hombres..." (Una reza) 
"los troperos de oro envueltos en los ponchos de oro -a veces negro a veces rojo celeste verde- y el caballero que repasa las lagunas de los oros."(Tembladerales de oro).

"Lentamente mi balsa invade las aguas de la conciencia (...) mi balsa desnivelada por el viaje de una mulata por el agua rosada (entre caídos tacuarales) (La balsa de los colores).

La poesía es asumida como compromiso con la gente del Pais Natal:

"Yo, el rastreador (...) oh mis pequeños seres del desamparo, canto mi canto con un lenguaje impopular, pero cercano a vuestros vestidos miserables". (EI canto impopular).

Los poemas de Aguatrino (1976), nacieron, según el autor, de una constante y antigua relación entre el mar del este uruguayo y las llanuras acuáticas de Corrientes.

Están presentes semas ya analizados en obras anteriores como el AGUA (esteros perseguidos, esteros marinos, mar, lagunar), el PAISAJE (palmar, tembladeral, islas, pajonales, pantanal, caliente tierra), la GENTE (los gauchos más huraños, la mulata de blanca llamarada).

Aparecen semas que se repetirán más adelante como ZORZAL, TRINOS, con una significación simbólica personal.

Por primera vez aparece la siguiente estructura sémica: "ser Criollos hasta la Ultima Coronación de la hermandad", relacionada directamente con la misión del poeta.

En Llegada de un Jaguar a la Tranquera (1980), se repiten semas y construcciones sémicas de textos poéticos anteriores.

Se incorporan semas criollos y guaraníes. El paisaje y su gente son a veces particularizados (Arazá-Ti Rincón, Trapiche Cué, Teodoro Frutos, Luicho Merlo, la negra Jerónima).

Nuevamente están los semas referidos al AGUA, el PAISAJE, y la MEMORIA ("paraje correntino","memoria sangral del agua madre").

Se desarrolla el sema TRINO asociándolo al sema PADRE (el Caballero de los Trinos, mi padre, me traes ahora un Trino Blanco para desterrar de mi corazón al Trino Negro")(El bayo ruano).

Se utiliza nuevamente la estructura sémica "La Ultima Coronación de la hermandad" (Llegada de un jaguar...)

Se asocia por primera vez el sema COSMOS al sema CORRIENTES ("sueño nataluniversal del Cosmos Correntino") (EI tren casi fluvial),

Los dos últimos libros: Una Acuarela Móvil (1985) y Resplandor de mis Bárbaras (1967-1985), profundizan en la utilización de semas intertextuales a lo largo de la obra reunida y se presentan como sintesis de las obsesiones del poeta.

Deseamos señalar, que el corpus poético total (El tren casi fluvial), permite ser analizado e interpretado como ondas acuáticas concéntricas. El texto poético parte de semas universales, no particularizados y los profundiza, amplia, particulariza 
progresivamente, hasta lograr una sintesis entre lo universal y lo particular, lo aludido y lo nombrado insistentemente.

"El texto no es un conjunto de enunciados gramaticales o agramaticales, es lo que se deja leer a través de la particularidad de esa reunión de diferentes estratos de la significación aqui presente en la lengua cuyo recuerdo evoca: la historia": (21)

\section{EL DISCURSO AJENO EN EL ESPACIO TEXTUAL:}

Nos queda por abordar lo que denomináramos INTERTEXTUALIDAD DE PRIMER GRADO, donde el texto ajeno está presente como reminiscencia o como cita.

Para ello, y siguiendo a Kristeva, (22), consideraremos el espacio textual como un espacio de producción de relaciones. La palabra en el espacio textual se define por dos tipos de relaciones: relación sujeto-destinatario y relación con el corpus literario anterior o sincrónico.

Hemos ya analizado la primera de estas relaciones al considerar la autointertextualidad de Madariaga como estrategia textual. En esta segunda parte de nuestro trabajo, analizaremos las relaciones (y deudas) del poeta con el texto de otros autores de vanguardia, anteriores o contemporáneos.

La apropiación del texto ajeno permite que el lenguaje aparezca como diálogo de textos; el texto poético está así doblemente orientado: hacia la evocación de otra escritura (reminiscencia) y hacia la transformación de esa escritura en texto propio (intimación) (23).

El texto ajeno, incorporado como reminiscencia o como cita, debe ser deconstruído para su incorporación, donde es construído nuevamente dentro de otro espacio textual.

En nuestro análisis, hemos podido observar reminiscencias o citas de autores anteriores y reminiscencias o "correspondencias" con autores contemporáneos o coterráneos.

Podemos, mediante los ejemplos, hablar de influencias o de apropiación consciente o inconsciente de textos poéticos con respecto a los primeros. En cuanto a los autores contemporáneos, hemos analizado "correspondencias" intertextuales, reminiscencias de contenido o utilización de ciertos semas comunes. Los textos poéticos de autores coterráneos (Portela, Alvarenga) presentan también correspondencias con los textos de Madariaga e incluso, como en el caso de Portela, citas textuales de los mismos. Tal como lo enunciamos, hemos trabajado en tres planos:

1-Citas o reminiscencias provenientes del surrealismo o de autores anteriores a Madariaga.

2-Reminiscencias con autores contemporáneos (Bayley, Aguirre, Molina) Intertextualidad con un autor de su misma generación (Veiravé)

3-Reminiscencias o correspondencias entre textos de Madariaga y textos poéticos de autores correntinos (pertenecientes a la generación del 70) como Portela y Alvarenga.

Hemos dicho ya que nuestro autor pertenece a la llamada "generación del 50", caracterizada por la práctica vanguardista. "La vanguardia del '50 utiliza de algún 
modo la premisa de escribir en contra de la gramática, violentándola. Invierte la sintaxis de la frase y la imagen se instala en primera fila. Lo que hacen es concebir al lenguaje poético como lo diferente del lenguaje hablado. La metáfora radicalizada es el ejemplo más claro de la constitución del código poético de la vanguardia. (24) Madariaga se acerca al discurso de la vanguardia a través de autores como Girondo (perteneciente a la vanguardia de la década del 20 pero que nuclea a su alrededor a los vanguardistas del 50), Molina y Pellegrini, con quienes lo unía la amistad y a quienes les debe el haber podido acceder a documentos surrealistas excelentemente traducidos.

Dentro de la vanguardia de los años 50 , existieron en nuestro pais dos corrientes: la surrealista (deudora del surrealismo europeo) y la invencionista. El grupo surrealista del que participaba Madariaga y que comprendia poetas como Molina, Pellegrini, Llinás, Vasco, Latorre, publicó dos revistas donde aparecían frecuentemente textos de los surrealistas franceses: A PARTIR DE CERO y LETRA Y LINEA, continuadora de la anterior. Pero este grupo participaba también de las actividades y publicaciones del grupo invencionista, creado por Bayley y que tuvo su medio de expresión en la revista POESIA DE BUENOS AIRES

Dirigida por Raúl Gustavo Aguirre. Madariaga dice haber tenido una buena e importante relación con ambos grupos, no haber estado encasillado específicamente en el grupo surrealista.

Veremos cómo, su lenguaje poético, además de reminiscencias de otros textos surrealistas, posee también ciertas correspondencias con el lenguaje de los autores invencionistas mencionados.

Aunque más joven que sus companieros surrealistas, Madariaga continuará dentro de la misma línea en la cual se formó, a pesar de haber publicado la mayoría de sus libros entre los 60 y los 70 . Pero en su poesía no están presentes elementos característicos de estas generaciones como el coloquialismo y el compromiso político. Madariaga siguió y sigue reivindicando la absoluta libertad de la poesía y el compromiso ineludible y único del poeta con el hecho poético, postura heredada del surrealismo.

\section{FRANCISCO MADARIAGA Y LA VANGUARDIA:}

El discurso poético de Madariaga, permite inscribirio dentro de lo que Yurkievich llama la "directriz subjetivista de la vanguardia", aquella donde "el texto registra las perturbaciones de la conciencia, se deja cautivar por lo psicótico, explaya los estados mórbidos, las angustias desorganizadoras, el dislocamiento provocado por una espontaneidad descontrolada, el desvarío fantasmal, las alteraciones de los lazos objetuales, el irreprimible autismo que to retrotrae y lo avasalla al cohabitante insondable: el inconsciente."(26)

"El único vínculo con el afuera es la cita velada o explícita, la alusión y apropiación de la palabra de los otros (...) el registro de lengua utilizado (sintaxis, formas verbales, léxico) también alude a esta cita prestigiosa, a un lugar sacralizado (ese otro lugar), la poesía, sólo acceden las palabras incluídas en la circulación de los discursos culturalmente prestigiosos."(27) 


\section{El texto ajeno como cita: \\ EI texto poético TRINOS BLANCOS O NEGROS (UAM, 1985), es un claro ejemplo de intertextualidad. En él, Madariaga se refiere a sus lecturas e incorpora al texto poético citas textuales de otros autores (Rimbaud, Góngora, Shelley, Lautréamont, Breton, Pellegrini) que nos permiten deducir las influencias, relaciones y coincidencias con los mismos.}

\section{El texto ajeno como reminiscencia:}

Encontramos en el texto poético estudiado (EL TREN CASI FLUVIAL), reminiscencias de Rainer María Rilke:

"Me interesan los poetas que lo son por indicación de las lejanísimas razas-madres de la naturaleza, (...) debe viajar a las ciudades más agigantadas y a las naturalezas más veloces y variadas, y, por sobre todo esto, debe oír sonar el mar y su esbeltez en el alba... (Cartas a poetas, mercaderes y seudoaristócratas de nuestro tiempo, LTDLS).

Dice Rilke en Los Cuadernos de Malte Laurids Brigge:

"Para escribir un solo verso, hay que haber visto muchas ciudades, hombres y cosas, hay que conocer los animales, sentir como vuelan los pájaros y saber qué movimientos hacen las florecillas al abrirse por la mañana."

También reminiscencias de Rubén Dario, aquél que en Cantos de Vida y Esperanza, decia:

"y muy siglo diez y ocho y muy antiguo

y muy moderno, audaz, cosmopolita

con Hugo fuerte y con Verlaine ambiguo

y una sed de ilusiones infinita. (Yo soy aquél)

En Arte Poética Príncipe y Pirata (EAV), el texto de Madariaga expresa:

"Y después?... mucho más, y mejor, y más libre, y más moderno, más hombre. Oh alemanes, on Rimbaud, Lautréamont, Apollinaire, y vosotros, los mejores surrealistas. Y los amores. Y el amor."

En los primeros libros de Madariaga, encontramos también reminiscencias del Neruda de Residencia en la Tierra:

"Sucede que me canso de ser hombre./Sucede que entro en las sastrerias y en los cines/ marchito, impenetrable, como un cisne de fieltro, navegando en un agua de origen y ceniza./ El olor de las peluquerias me hace llorar a gritos./ Sólo quiero un descanso de piedras o de lana./sólo quiero no ver establecimientos ni jardines/ni mercaderias ni anteojos ni ascensores." (Walking around) 
origen y ceniza./ El olor de las peluquerias me hace llorar a gritos./ Sólo quiero un descanso de piedras o de lana./sólo quiero no ver establecimientos ni jardines/ni mercaderías ni anteojos ni ascensores." (Walking around)

"A veces camino por los extraños y ponzoñosos mundos/ del interés humano y me desmorono entre el color /sórdido del desaliento en sangre, en desayuno/de odio y sangre". ( Madariaga, No hay penitencia, EDN).

"Yo lloro en medio de lo invadido, entre lo confuso, lentre el sabor creciente, poniendo el oído/ (...) cediendo sin rumbo el paso a lo que arriba/ a lo que surge vestido de cadenas y claveles.".(Neruda, Débil del alba).

"Con un don infernal de encanto y de sonido/lloras entre los hombres tu desacuerdo /con el lenguaje..." (Cenit con reportaje, EPP)

"Tú estás de pie sobre la tierra, llena/de dientes y relámpagos"(Neruda, Oda con un lamento)

"Adorada mía tapizada de rayos/con tu colina bajando todas las aguas de la locura" (El riesgo de la verdad, EPP)

"Tú, incrustada en el ataúd de los/ relámpagos"(Los peldaños infinitos, EPP)

"Es el viento qe agita los meses, el silbido de un/tren "(Neruda, Colección Nocturna)

"Ahora bien, en lo largo y largo, /de olvido a olvido residen conmigo/ los rieles, el grito de la lluvia: lo que la oscura noche preserva". (Neruda, Madrigal escrito en invierno)

"El sonido de un tren que se ahoga en la/catarata de las hojas./(...) estoy entre la espada del paisaje y el/ ladrillo caliente del olvido, viajando con un ardor de joya y sangre": (La selva liviana, EPP) 
Madariaga, fue el medio de transporte por medio del cual llegó a Corrientes, partió y volvió cuantas veces pudo.

Las reminiscencias de Neruda y Rilke, tienen su explicación en la gran influencia que estos dos autores, junto con Milosz, tuvieron en la década del cuarenta, época de formación y absorción para Madariaga.

\section{LAS REMINISCENCIAS DE TEXTOS SURREALISTAS:}

Madariaga reconoce la influencia que los poetas surrealistas europeos ejercieron sobre él. El lenguaje surrealista fue para él como una puñalada, una puñalada que no lo mató, pero que dejó en él una marca indeleble al tiempo. Reconoce entre sus autores preferidos a Aimé Césaire, René Char, Aragón, René Crevel, Pierre Unik... (29)

"Después de todo esto las armas europeas- y de otros continentes- me detuvieron en mi camino, y apuñalearon, en mí, al centro de oro del agua del espíritu, alli donde se originan los tembladerales y los manantiales de vida-muerte de la raza de la poesía, y los puñales rebotaron, con las imágenes prendidas a los filos de su sangrante resplandor..." (Palmeras en el agua, UAM)

Con respecto a Aimé Césaire (uno de los más ortodoxos poetas surrealistas, nacido en Martinica), se observan en el texto de Madariaga, los dos tipos de INTERTEXTUALIDAD DE PRIMER GRADO:

\section{a)el texto ajeno como cita:}

"elevando la estirpe real de los almendros de la esperanza" (Césaire, Supervivencia)

La intertextualidad es consciente, el conjunto sémico tomado de Césaire, es utilizado como cita y señalado entre comillas:

"Y qué me habrá quedado?

"¿El almendro real de la esperanza?" (El bayo ruano, LDUJALT)

\section{b)el texto lajeno como reminiscencia:}

I-"Te evoco/bananero patético que agitas mi corazón desnudo en el día salmodiante" (Césaire, Supervivencia)

"Te evoco palmar colorado del unilico/ corazón del hombre, esta noche." (Palmares colorados, RDMB)

(ambos textos están desarrollados como estructuras sémicas paralelas)

II-“sol serpiente ojo fascinador ojo mio. (Césaire, Sol Serpiente)

"castigado por una voz que sale de los ojos/del sol (Terrores coloniales, EDN) 
I-"Te evoco/bananero patético que agitas mi corazón desnudo en el día salmodiante" (Césaire, Supervivencia)

"Te evoco, palmar colorado del unílico/corazón del hombre, esta noche." (Palmares colorados, RDMB)

(ambos textos están desarrollados como estructuras sémicas paralelas)

II-"sol serpiente ojo fascinador ojo mio. (Césaire, Sol Serpiente)

"castigado por una voz que sale de los ojos/del sol (Terrones coloniales, EDN)

(conjuntos sémicos semejantes)

III-"el azúcar de la palabra Brasil en el fondo de la ciénaga" (Césaire, Sol Serpiente)

"Me olvidé de la poesía? Ella era una sonrisa coralina en el fondo de un pantano"

(Otras apariciones, RDMB)

IV-"las selvas en marcha por el cuello sangrante del mundo" (Césaire, Supervivencia) "la muerte habia largado toda su sangre en el estero" (Sociedad al Natural, EDN)

$V$-"y el infantilismo del alfabeto de los espasmos que hacen los/grandes ramajes de la herejía o de la connivencia"(Césaire, Las armas milagrosas)

"Es la gala del orden del que participaban las fieras, el infantilismo penal" (El agua de la selva, LSDS)

(utilización de semas o conjuntos sémicos que remiten a sentidos semejantes)

Semas que relacionan ambos lenguajes: AGUA, SELVA, SANGRE (vertida, derramada), DEGOLLACIONES, SERPIENTES, BANANOS, PLANTAS ACUATICAS.

Aún cuando los conjuntos sémicos no sean totalmente idénticos, en los primeros libros de Madariaga se respira el aire del lenguaje poético de Césaire. El poeta correntino, en la entrevista, dice haber conocido la poesía de Césaire a través de Molina, quien se lo dio a leer después de publicado El Pequeño Patíbulo, asombrado por la coincidencia entre ambos lenguajes. (30)

El lenguaje poético de Madariaga, presenta también reminiscencias de los aforismos A LA SALUD DE LA SERPIENTE, de René Char:

"La poesia es de todas las aguas claras la que menos se demora ante los reflejos de sus puentes"(René Char)

"Se es poeta por una amplia sonrisa de las aguas"(Arte poética príncipe y pirata, EAV) 
"Ser cantor es (...) desarrollarse como el agua, (la que surge o corre)" (Carta a poetas, LTDLS)

"Si habitamos un relámpago, alli está el corazón de lo eterno" (Char)

"No tengo más que un pais caliente como un rayo"(Aparición duerme, EDN)

"A la salud de la serpiente" (Char)

"No se arranca la boca verbal de la serpiente./Se duerme al viejo y fresco sudor de su garganta"

(Exploración fluvial, EDN)

Hallamos también reminiscencias de Aragón:

"Dadme el lenguaje tenebroso de los ajusticiados (...) / el vocabulario último de los guillotinados. (Aragón, Licantropia contemporánea)

"hacen que yo busque, con desesperación inmóvil, los/ ruidos de otra época lejana: los ronquidos de los degollados en las orillas del juncal": (La Balsa Mariposa, OP)

Hasta aquí, hemos rastreado reminiscencias del lenguaje poético de algunos poetas surrealistas en textos de Madariaga.

Pudimos observar la presencia de semas o conjuntos sémicos semejantes y de una misma postura frente al hecho estético.

En la poesía de Francisco Madariaga existen también ciertas correspondencias con la poética de autores como Bayley y Aguirre, pertenecientes al grupo invencionista Poesía de Buenos Aires.

\section{EJEMPLOS DE CORRESPONDENCIAS CON EDGAR BAYLEY}

"hablo de la sed y el sueño líquido del hombre" (Bayley, Los hombres y los años)

"mi sed, mi litoral inquieto" (Bayley, Bienvenida de los dias)

"el agua es el deseo inmortal" (Los correos natales, LJDS)

"el agua exorbitante está en mi boca"(Apariciones)

"Debe importarme el agua y el color./Nada más (id)

"tu riqueza está aquí/volverás a la tierra/a tu viaje de siempre" (Bayley, Ando sobre la tierra)

"y no podría dejar de cantar su corazón, que sólo busca enterrarse (...)/sin poder desligarse de la tierra". (El paraíso del estero, RDMB)

"no podré salir nunca del hechizo natal" (Palmares colorados, RDMB) 
"hasta el día de La Ultima Coronación: /la de la hermandad, cuando, junto a un Gran Fogón/al ras del suelo, se arreglen las cuentas con la Vida a nivel del horizonte."(Llegada de un jaguar... LDUJALT)

"Uno quisiera entrar, quedarse, /en el silencio de antes, para siempre./y sangrar sin adornos."(Aguirre, $Y$ uno les ruega a las palabras)

"Me sangra la poesía por la boca"(Carta de enero, EDN)

"el poema suele ser a veces ese crujido aterrador/tras una puerta clausurada"(Aguirre/Aforismos)

"el reinado/de los terrores de la poesia"(Cartas a poetas... LTDLS)

"Aterrorizados por los paisajes de la/poesía (Palmares colorados, RDMB)

"el poeta es el hombre de la lenta obsesión"(Aguirre, id)

"Hace veinte años que quiero relatar perdidas cosas./No puedo iniciar nada que no sea el torpe vicio de/mi alma de grabarse y retorcerse"(Cartas de invierno, LJDS)

\section{ESAS EXTRAÑAS COSTUMBRES DE TATUARNOS EL ALMA CON LA CORRIENTE:}

El lenguaje poético de Enrique Molina y sus correspondencias (relaciones y similitudes) con el de Francisco Madariaga, merecen una lectura atenta. Las obsesiones comunes por determinados temas y la utilización de semas similares o idénticos, permiten sentir entre ambos lenguajes lo que Madariaga definiera como un "aire de familia". (31)

A Molina y Madariaga no sólo los une la amistad y la militancia en el surrealismo, también tienen experiencias de vida paralelas: una infancia vivida en el paisaje subtropical y una adultez desgajada del mismo. $Y$ es ese paisaje común el que se filtra en ambas poéticas.

Temas comunes a ambos son los viajes (Semas: TRENES, PASAJEROS, VIAJEROS), la tierra, el agua (litoral y oceánica. Semas:RIO, ESTERO, OCEANO), la vegetación del subtrópico (Semas: BANANOS, NARANJAS, PLATANOS), la gente del litoral (mulatas, criollos, personajes típicos), la memoria, el desamparo, los fantasmas y apariciones, la fauna subtropical (Semas: MONO, YACARE, LOROS), la sangre y las degollaciones.

"cautivos como monos en el lago" (Molina, Archipiélagos lánguidos)

"Yo quiero cautivar tu desesperación, on mono/adiós./Tiembla tanto en tus islas negras, oh mono/adiós"(Lágrimas de un mono?,EPP) 
"El tren ahogado lento con orejas de lluvia./El tren de roncas venas de ceniza" (Molina, La maleta de piel de pájaro)

"El sonido de un tren que se ahoga en la /catarata de las hojas" (La selva liviana, EPP)

"con su jergón tirado contra el turbio mamparo"(Molina, Un hálito doliente)

"(Yo pertenezco a la intemperie/Reclamo el honor de mi especie/la idolatria de mis venas/mi desamparo en la corriente)"(Molina, En ruta)

"Memoria y desamparo"(Molina, Francisca Sánchez)

"la majestad del trópico en el gran desamparo de los años "(Molina, Archipiélagos lánguidos)

"Lo inmediato no aparece ni desaparece/está desnudo en medio del contraamparo" (Contraamparo, OP)

"estoy entre los vientos del cielo o del/contraamparo" (Palmares colorados, RDMB)

"y las miserias artificiales del/desamparo"íd

"Ahí golpearon la aldaba los gitanos/con un pobre pandero, /y las gentes llegaban desde el rio/(...) Ahi está el traficante de tortugas, /el hombre de pollera de lona con el pescado suspendido de un palo/y quien trueca la víbora por un jarro de caña..."(Molina, Soledad; Qué hermosa es la tierra!)

"...carretas, /musiqueros natales, /buhoneros, /enterradores, /labriegos, /domadores, troperos, /promeseros, /bandoleros, /cuatreros, /cazadores-mariscadores..."(La Balsa Mariposa, OP)

"y el errante ataúd de la memoria/lleno de fantasias y fracasos y furias amordazadas/aguas aguas aguas"(Molina, Rito Acuático)

"y un ataúd de otro oro, /aparecia y desaparecia/en el borde del pantano"(El ataúd de oro, RDMB)

"como el Océano Pacífico cuando se envuelve la garganta (...)para disimular la herida de su degollación." (Molina, Sangre viva)

"sangrias flotantes de degollaciones, en esterales" (Una acuarela móvil)

"junto al tesoro irradiante de otro cuerpo en incomparables mañanas con un terrible tajo en la garganta"(Mo!ina, Sangre viva)

"abrazadas a los cuerpos de los degollados" (Apariciones, UAM) 
"como el Océano Pacífico cuando se envuelve la garganta (...)para disimular la herida de su degollación." (Molina, Sangre viva)

"sangrias flotantes de degollaciones, en esterales" (Una acuarela móvil)

"junto al tesoro irradiante de otro cuerpo en incomparables mañanas con un terrible tajo en la garganta"(Molina, Sangre viva)

"abrazadas a los cuerpos de los degollados" (Apariciones, UAM)

"algún machete, quizás, entre las malezas, degollador" (Molina, A simple vista)

"los ronquidos de los degollados en las/orillas del juncal"(La Balsa Mariposa)

"hay que poblar de fantasmas esos terrenos salvajes"(Molina, Etapas)

"De esas tierras con habitantes de llanurales(...) cuyas ánimas perviven, hurañas y brillantes" (EI tren casi fluvial)

Hemos visto como, en el texto poético de Madariaga, se jugaban relaciones y significados provenientes de otros lenguajes, cada uno de ellos con sus características propias, pero que influían y penetraban el espacio textual estudiado por nosotros (EL TREN CASI FLUVIAL).

Al comparar los ejemplos, hemos podido observar con algunos, ciertas reminiscencias de contenido, con otros, reminiscencias formales, con la utilización de semas o conjuntos sémicos similares o idénticos.

Debemos sí señalar, cómo, a pesar de cierto "aire de época" o correspondencias intertextuale con otras poéticas, la de Madariaga es absolutamente original en si misma. Todo texto se construye siempre como mosaico de citas, es absorción y transformación personal, íntima, de otros textos (32), sin que esa operación (a veces consciente y otras no) signifique falta de originalidad en la producción del texto poético. Las combinaciones que pueden realizarse dentro del lenguaje poético son, como en la alquimia, prácticamente infinitas, las citas o reminiscencias ajenas no quitan valor al producto final, al contrario, lo enriquecen, porque el elemento ajeno es reciclado e incorporado a un nuevo contexto con un sentido renovado.

"Vanguardia siempre ha sido, justamente, eso; una red de contactos y diferencias con la cultura de su momento"(33)

\section{EL TREN CASI FLUMAL COMO GENERADOR DE INTERTEXTUALIDAD:}

El poeta Alfredo Veiravé, pertenece a la misma generación (por edad) que nuestro poeta estudiado. Sin embargo, su poesía se halla inscripta en los códigos de la poesía del '60 (34). En la entrevista que realizáramos, el poeta entrerriano admite sentirse 
Con respecto a Milosz, hay un ejemplo de intertextualidad que une la poesía de Veiravé y Madariaga: la "extraña muchacha de párpados arcangélicos".

Ante la mención de este ejemplo, Madariaga respondió que lo había tomado directamente de Milosz, de un poema aparecido en una revista literaria por la década del 50, muy bien traducido. (36)

Veiravé contestó:" aquél verso se lo robé a sabiendas (a Madariaga) y con el cariño que me inspira su timidez, su pudor, su hombria, más bien como una nota de humor. El me aclaró que ése era un verso de Milosz..."(37)

No hemos encontrado el poema original de Milosz, pero sí podemos confrontar el distinto tratamiento que ambos hacen en su lenguaje, del texto ajeno. El conjunto sémico al que hacemos alusión aparece también autointertextualizado dentro de la obra de Madariaga, donde se encuentra incluído en dos poemas de diferentes obras. En Veiravé también se lo encuentra en dos poemas, pero de la misma obra.

"Y la extraña muchacha de párpados /arcangélicos/ custodiada por una rigurosa mulata, /adónde iba, en ese carruaje de los /esteros?..." (La Guerra del Paraguay, OP)

"Balsas con alguna rigurosa mulata-armada hasta los dientes-que cuida de una /doncella especial de "párpados arcangélicos"..." (Apariciones, UAM)

En Veiravế, el conjunto sémico aparece en su libro RADAR EN LA TORMENTA (Sudamericana, 1985):

"La muchacha de párpados arcangélicos, blue jean y /zapatillas blancas, camina delante de Anacreonte/haciendo bailar su lacio pelo sobre la espalda desnuda/intuyendo que asi va a salir retratada en el poema". (Falsos prestigios)

"(Una joven de párpados arcangélicos y blue jean/ he ha mirado con sus ojos muertos: cabellos negros y profundos/del sueño como esos murciélagos de las pesadillas que revolotean/en la noche de la caverna donde eligen al azar/el cuerpo de sus víctimas)". (Alicia en el país de lo no visto o la nieve del verano)

Otro ejemplo de intertextualidad consciente en el lenguaje poético de Veiravé, con respecto al de Madariaga, se encuentra en su último libro LABORATORIO CENTRAL.

EI libro lleva como epígrafe unos versos de Madariaga tomados del poema Imagen del poeta y contiene un poema titulado El Lenguaraz donde encontramos semas tomados de la poética de Madariaga. Estos semas comunes son: TABACO, MEMORIA, CABALLOS (de distintos colores), semas utilizados con frecuencia por Madariaga en sus poemas. Veiravé los incorpora conscientemente, como un homenaje al Doeta correntino.

"Tabaco del ocio podrido" (Estafetas virginales, LJDS)

"su tabaco de miel arrollado por el invierno" (El canto impopular, TDO)

"bebiendo, en enigmática mascada, el agua del tabaco"(Apariciones, UAM) 
"país que lava su boca con el agua del tabaco" (Palmeras en el agua, UAM)

"El lenguaraz... / prendió su vieja pipa con tabaco correntino" (El lenguaraz)

"en la conciencia de su memoria, siempre fulgurante, sangral y móvilmente" (EI tren casi fluvial)

"Los recuerdos sonrien, duelen o mandan mensajes/desde el pecho y desde las fogatas de la memoria"(EI lenguaraz)

"Potrillos de oro sanguíneo" (Apariciones, EDN)

"el antiguo bayo ruano"(El bayo ruano)

"un caballito color de cidra"(Puente Florencia, LDUJALT)

"un baguaiito color de llamarada"(Mediodia de un remate... LDUJALT)

"mi caballo era de color sanguíneo" (Canciones para D.H.Lawrence, id)

"potrillos color oro de luna"(Arazá-ti Rincón, íd)

"¿El tobiano? ¿Dónde estará el tobiano?" (Paso Cabral, RDMB)

"y del color de los caballos/tobianos/azulejos/colorados" (El Lenguaraz)

El primer ejemplo que vimos con respecto a la intertextualidad entre Madariaga y Veiravé, mostró, como un verso de Milosz, intertextualizado por Madariaga, es a su vez transferido al lenguaje poético de otro autor contemporáneo.

El segundo ejemplo, referido a los semas presentes en EI Lenguaraz, es ejemplo no de intertextualidad en Madariaga, sino de desplazamiento de semas de su poética a otro lenguaje. El generador de intertextualidad es en este caso El tren casi fluvial.

Debemos aclarar que no siempre es posible, como ahora, llegar a delimitar quién es el deudor (el "antropófago"), pero to que interesa realmente en los casos de intertextualidad, es ver cómo cada poeta trabaja personalmente con los mismos elementos.

\section{LA POESIA, ESE DELITO NATAL:}

Oscar Portela y Martín Alvarenga, poetas correntinos pertenecientes a la generación del 70 presentan ciertas correspondencias con la obra de Madariaga. A los tres los une el mismo encantamiento ante el paisaje natal, en los tres hay semas similares para referirse a él. A pesar de las diferentes cosmovisiones poéticas de cada uno, hemos encontrado reminiscencias en los tres lenguajes.

Portela es el que tiene una relación más cercana con Madariaga: ha escrito ensayos sobre su obra, ha prologado sus libros, Madariaga le ha dedicado poemas y ha prologado a su vez MEMORIAL DE CORRIENTES. La intertextualidad entre ambos es más consciente, a pesar de las diferencias estéticas que los separan.

"Es evidente que Madariaga fue para mí un descubrimiento fulgurante" (O.Portela)(38) 
une el mismo encantamiento ante el paisaje natal, en los tres hay semas similares para referirse a él. A pesar de las diferentes cosmovisiones poéticas de cada uno, hemos encontrado reminiscencias en los tres lenguajes.

Portela es el que tiene una relación más cercana con Madariaga: ha escrito ensayos sobre su obra, ha prologado sus libros, Madariaga le ha dedicado poemas y ha prologado a su vez MEMORIAL DE CORRIENTES. La intertextualidad entre ambos es más consciente, a pesar de las diferencias estéticas que los separan.

"Es evidente que Madariaga fue para mi un descubrimiento fulgurante" (O.Portela)(38)

En Alvarenga, existen semas o conjuntos sémicos semejantes a los de Madariaga, pero atribuímos estas correspondencias al intento de rescatar en la memoria y el lenguaje un mismo espacio natal.

\section{La intertextualidad en MEMORIAL DE CORRIENTES (O.PORTELA)}

Ya en HABIA UNA VEZ (1983), libro anterior de Portela, encontramos algunos semas relacionados con la obra de Madariaga:

"...y ya no/es del trino, /sino del ultratrino bien/ardiente" (Un aparte para trinos, AT)

"sólo un trino de amor/que se destrina" (Portela, p23)

"zorzal bandolero semisalvaje" (Un aparte para trinos, id)

"zorzal bayo de mi infancia" (Portela, p16)

"No soy el espectral, ni el sangriento, ni el cautivo, ni el libre. (Nueva Arte poética,EDN)

"del pasado no vivo/sino espectral/y sangrante como yo" (Portela, p50)

¿El alba guaraní gime en mi memoria? /Oh francés degollado por las aguas!(Carta de enero, EDN)

"memorias de albas, agua, sangre"(Portela, p59)

EI epilogo de MEMORIAL DE CORRIENTES dice: "Memorial de Corrientes es el imposible retorno a un "pequeño patíbulo" donde cumplo esa condena que todo "delito natal" exige de quienes se ven arrojados a la imposible soledad de un habla que debe quererse para ser ante todo como destino. (....)Cruzaré finalmente en una "balsa mariposa" hacia los asilos donde apartado canta la recepción de los que esperan el alba en lo más dorado del ocaso?". Observamos en este texto, la intertextualización de conjuntos sémicos utilizados por Madariaga como títulos para sus poemas.

Conjuntos sémicos similares: 
"Y los jabuares domesticados por el hombre"(Portela, Estaciones)

Otros semas recurrentes en la obra de Portela y que comparte con el lenguaje de Madariaga son: AGUA (estero, lagunas, mareas), TIERRA, ELEMENTOS (fuego, aire, agua, tierra), MEMORIA, AMPARO, SANGRE, SANGRANTE, FANTASMAS.

\section{Correspondencias entre EL TREN CASI FLUVIAL y el lenguaje poético de Martín Alvarenga:}

Existen ciertas correspondencias entre los textos poéticos de Madariaga y los de Alvarenga. Aparecen en ambos lenguajes semas comunes referidos a Corrientes: MEMORIA, AGUA (río, estero, laguna), BALSAS, CANOAS, TREN, VEGETACION (plátanos, naranjas, palmeras), FAUNA (tigre, yacaré), incorporación de voces guaranies, la gente correntina (afrocriollos, criollos, mulatos, indígenas, mestizos).

Además de compartir estos semas, lo que relaciona fundamentalmente a las dos poéticas es la concepción de Corrientes como Cosmos y el deseo de lograr una hermandad poética, una comunidad poética:

"el animita viva del Cosmos Correntino" (LDUJALT)

"Sueño natal-Universal del Cosmos Correntino" (El tren casi fluvial)

Alvarenga crea toda una cosmogonia referida a Corrientes a partir de mitos universales, orientales, latinoamericanos, guaraníes y personales:

"ícono de barro y agua/Poderoso Estado Solar" (Corrientes, Cantando como si naciera)

"mi pais adolescente o continente niño capa geológica descolgada de su germen"(id) "todas las razas/sentadas/como un yoghi/ un payé un amauta/Pensamiento Yerbero/ reinando en el cosmos"(Brotecito, Flotilla de fábulas)

*Para Madariaga Corrientes es:

"PAIS DEL DIA PURO" (Mediodía en un remate, LDUJALT)

Para Alvarenga:

"País de la Luz" (Sol sumergido, Cantando como si naciera)

"País Luminoso" (íd)

"Poderoso Estado Solar" (Corrientes, Cantando como si naciera)

"país de radiaciones solares" (Poesía como habitación cósmica, Cantando como si naciera)

*Los semas que designan a la tierra natal, se hallan en ambos relacionados con el sema sangre: 
"Ese tambor de sangre es tu pais" (El verdadero país, EPP)

"el trópico en forma de sangre dando tumbos por mi memoria" (Alvarenga, Quehaceres, Flotilla de fábulas)

"La "hermandad poética":

"Hagamos una cadena de oro, agua y sangre anónima con los poetas..." (Trinos blancos y negros, OP)

"La Ultima Coronación: la de la hermandad" (Llegada de un jaguar...)

"y fundar la Comunidad Poética, la anunciación del retorno" (Alvarenga, Pulir un sol hablando con los abuelos, Flotilla de fábulas)

"Ambos defienden los "poetas naturales":

"Me interesan los poetas que lo son por indicación de las lejanísimas razas-madres de la naturaleza"(Cartas a poetas... LTDLS)

"Deberiamos ir hacia los Poetas Biológicos" (Alvarenga, Pintura ingenua, Flotilla de fábulas)

"En contraposición con los "poetas oficiales":

"Perros, enanos entecos, tenéis a vuestro servicio/ los escribientes nacionales, pajarracos de/la patria... (Los poetas oficiales, LJDS)

"la impostación y los cenáculos y toda esa mala invención de la época y de la prensa no basta con criticar a los poetas oficiales uno tiene que renunciar al funcionario que tiene adentro"(Alvarenga, El verdadero exilio, Cantando como si naciera)

ॠRecuperación de la memoria a través de vehículos fluviales:

"Siempre he vuelto y volveré a esa República Natural y Joyante, para recorrerla: en trenes, en balsas, en vapores, en carretas, en canoas..."(El tren casi fluvial)

"La balsa mariposa que una noche diurna/de tormenta/ me condujo a un palmeral acuático..."(La balsa mariposa, OP)

"se trata más bien de soltarse en una balsa... /casi cuatro años de viaje fluvial/casi cuatro años de enganchar la embarcación del pasado..."(Alvarenga, p78, Drogados por la luz) "ir a buscar a los abuelos con una flotilla de fábulas "(Alvarenga, Pulir un sol... Flotilla de fábulas)

*Pobladores de la campaña correntina:

"este peligroso señorío de caudillos, domadores, troperos, cuatreros y mariscadores cazadores de las aguas con el rictus de los ojos de la boca y del corazón igual al de sus antepasados gauchos guerreros... (EI tren casi fluvial) 
por la luz) "ir a buscar a los abuelos con una flotilla de fábulas "(Alvarenga, Pulir un sol... Flotilla de fábulas)

"Pobladores de la campaña correntina:

"este peligroso señorío de caudillos, domadores, troperos, cuatreros y mariscadores cazadores de las aguas con el rictus de los ojos de la boca y del corazón igual al de sus antepasados gauchos guerreros... (El tren casi fluvial)

"corazón de carne humana sacrificada por cuatreros feudales y abigeato por ladrones que firman con los dedos impresión digital y feudal marca de ganado colonial..."(Alvarenga, Corrientes, Cantando como si naciera)

"mulatas verdes de ojos dorados, que huian cuando las violencias o se deslizaban cuando los amores..." (Apariciones, UAM)

"la sangre española se hizo tutti fruti/con la india"(Alvarenga, Pintura ingenua, Flotilla de fábulas)

"viejecillas gauchi-afro-guaraníes"(El bayo ruano, LDUJALT)

"caimanera gauchi-afro-india"(Muerte de Luicho Merlo, id)

"País de jinetes criollos y también de paisanaje más indígena o mulato"(Palmeras en el agua, UAM)

"el afrocriollo pintó la tierra virgen"(Alvarenga, Sendero de las revelaciones, Flotilla de Fábulas)

"paraguayo correntino mestizo ultraterrestre/danza chamamé valseado"(Alvarenga, Leyenda, despojate de tu dolorcito imaginando, Flotilla de fábulas)

Aún cuando compartan semas similares y ciertos temas como el rescate del pasado y de la memoria, ambas cosmovisiones poéticas son totalmente diferentes y originales. Madariaga vuelve a su país natal, su gente, su paisaje, en un intento de rescatar a través del lenguaje, la tierra de su infancia, comprenderla y aprehenderla como elemento reparados frente al paisaje y existencia urbanos.

Martín Alvarenga, influído por los mitos precolombinos y por el zen, intenta desde su cosmos correntino aprehender y comprender Latinoamérica y el Universo.

\section{CONCLUSION:}

Hemos visto como Francisco Madariaga utilizaba la autointertextualidad (Intertextualidad de segundo y tercer grado) como estrategia textual, por medio de la cual se permitía, plagiando su lenguaje, repitiéndose en la memoria, alcanzar el origen de la escritura como experiencia vital. 
Corrientes), se relacionan mutuamente, aún cuando responden a posturas estéticas y cosmovisiones personales diferentes.

La poesía de Madariaga, inscripta en la vanguardia por su "directriz subjetivista" (39), el lenguaje utilizado (heredado del surrealismo), la utilización de "la palabra de los otros" para relacionarse con el afuera (40) y la realización de una "operación de doble transferencia como es la de transformar el incesante transcurrir temporal en espacio estático y mitificar ese espacio que el poema nombra para perpetuarlo y perpetuarse"(41), puede ser considerada como absolutamente original dentro de las poéticas de su generación.

Los libros de Madariaga, abarcados dentro de su obra reunida EL TREN CASI FLUVIAL, son como fulgurantes vagones encadenados e intercomunicados entre si. El lector puede transitar libremente de uno a otro y en todos encontrará el mismo olor: el del aire enrarecido por lo maravilloso y el de la ardiente humedad proveniente de la tierra y de los esteros natales. Dentro de cada vagón hallará objetos mágicos tomados de otros tiempos y otros espacios, objetos ajenos transformados por las manos poderosas del poeta, recuerdos, agua, fuego...

En los primero, las materias elementales y naturales asoman tímidamente entre el resplandor del lenguaje; progresivamente, estos elementos se van multiplicando, especificando, saturando todos los espacios.

Y siempre el paisaje... colándose por las ventanillas, iluminándolo todo, invadiéndolo todo con su clima, mientras el tren fluvial flota lento y memorioso sobre las aguas del Pais Natal. 
NOTAS:

1-"Este significado poético remite a significados discursivos distintos, de suerte que en el enucnciado poético resultan legibles otros varios discursos, creándose así en torno al significado poético un espacio textual múltiple cuyos elementos son susceptibles de ser aplicados en el texto poético concreto. Denominaremos a este espacio intertextual."(Kristeva J., Semiótica 2; p66/67)

2-"El tren casi fluvial"; Llegada de un iaquar a la tranquera.

3-Muschietti Delfina; Las poéticas de los 60 en Cuadernos de Literatura No 4; Instituto de Letras; Fac. Hum. ; Unne; 1989

4-Freidemberg Daniel; Prólogo a Criollo del Universo y otros poemas; Los Grandes Poetas; No 44; CEAL.

5- Entrevista "La urgencia del paisaje” en La danza del ratón/6; año 1984.

6-Yurkievich Saúl; A través de la trama; p15/16.

7."Si invento una palabra o una construcción inexistentes en cualquier lengua y siendo como tales un desafío a todo sentido, a todo significante, entonces escribo "la imposibilidad de lo imposible" (Badiou) y con ese gesto mismo, someto mi trabajo a las leyes intransigentes de la lengua, presente aqui frente a lo sobrerreal (del sobresignificante) que fuerzo.

Designando así el fondo infinito como un exterior imposible, permito que se lea mi lengua como acabada, limitada, cerrada. Tales "transgresiones" de tipo "surrealista", que apuntan a una infinitud sobre-material por estar por encima del significante real de la lengua, se convierten en la medida intema de un sistema lingüístico codificado: rechazándolas, la lengua cerrada y significativa indica sus propias censuras, o dicho de otro modo, permite determinados enunciados "transgresivos". (Kristeva; Semiótica 2: $p 122 / 123$ )

8-"entre los surrealistas, ya Breton declaraba que "Ias palabras hacen el amor". En su primer texto surrealista "Trabajos del poeta" también Paz se hace eco de esto y habla de "cópulas" entre palabras. Cópulas significa aquí "aglutinaciones, separaciones, ramificaciones". Volek Emil; Eros en rotación: La Semiología poética/La poética semiológica de O.Paz en los años sesenta.

9-"Atravesando, transgrediendo la palabra y la frase, el signo y la estructura, el significante que-se-produce dispone de una infinitud significativa en unidades gráficas o fónicas. "Infinitud significativa" quiere decir todas las posibilidades registradas o futuras de la combinación lingüística, los recursos ilimitados del significantes tales como diferentes lenguas y diferentes prácticas significativas los han empleado o ios utilizarán (...)"Unidad gráfica o fónica" en la que el infinito significativo existe, es el conjunto significativo mínimo aislado en el fenotexto. Un "conjunto" que para constituirse puede dislocar la palabra o no respetar sus confines, sea englobando dos lexemas, sea rompiendo uno en fonemas, con tal que recoja una serie no finita de sentidos...", Kristeva, Semiótica2; p116.

10-Kristeva; Semiótica 1; p47.

11-id. ,p236

12-Kristeva; Semiótica2 p67.

13-"El vegetal conserva fielmente los recuerdos de las ensoñaciones felices";

Bachelard G.; El aire y los sueños; p21. 
13-"El vegetal conserva fielmente los recuerdos de las ensoñaciones felices";

Bachelard G.; El aire y los sueños; $p 21$.

14-Monteleone J.; La noción de futuridad y la categoria de principio en la vanquardia hispanoamericana en Cuadernos de Literatura $N^{\circ} 4$; p44.

15-idem cita anterior.

16-Yurkievich S.; Los Avatares de la Vanquardia en Revista Iberoamericana $n^{\circ}$ 118/119; ene-jun 1982.

17-..."generar un texto significa aplicar una estrategia que incluye las previsiones de los movimientos del otro (...) por consiguiente, el Autor Modelo, deberá prever un Lector Modelo capaz de cooperar en la actualización textual prevista por él y de moverse interpretativamente igual que él se ha movido generativamente.

(Eco, U.; Lector in fabula; p79/80).

18-Entrevista a Francisco Madariaga

19- idem

20-idem

21-Kristeva, Semiótica 1, p20

22-Kristeva, Semiótica

23-ídem

24-porrúa, ana, Traficando palabras, p20

25-Entrevista a Francisco Madariaga

26-Yurkievich Saúl; Los avatares de la vanquardia, Rev. Iberoamericana

27-Muschietti,Delfina; Las poéticas de los 60 ,Cuad.de Lit. ${ }^{\circ} 4$

28-Salas Horacio, Generación Poética del 60,p26

29-Entrevista a Francisco Madariaga

30-ídem

31-ídem

32-Krsiteva,op.cit

33-Libertella Héctor, Patografía, vanguardia, posmodernidad, p103

34-"La frecuente utilización de mensajes publicitarios, frases de historietas y otros elementos brindados por la cultura de masas, inclinó a la poesía de los últimos años... hacia una marcada tendencia al collage y facilitó el acercamiento entre la forma poética y la narrativa..."(Salas Horacio, op.cit, p36)

35-Entrevista con Alfredo Veiravé

36-Entrevista con F.Madariaga

37-Entrevista con Alfredo Veiravé

38-Entrevista con O.Portela

39-Yurkievich Saúl; op.cit

40-Muschietti Delfina; op.cit

41-Monteleone,Cuad.Lit.nº 4 ,p39 


\section{BIBLIOQRAFIA}

\section{BIBLIOGRAFIA METODOLOOICA}

Asti Vera, Metodologia de la investigación; Bs.As; Kapelusz

Cohen Jean; El lenguaje de la poesía; Madrid; Gredos; 1982; Estructura del lenguaje poético; Madrid; Gredos; 1984.

Dallenbach Lucien; Intertexte et autotexte en Poétique27; 1976.

Eco Umberto; Tratado de semiótica general; Lumen; 1985; Obra abierta; Planeta; 1985.

Greimas A.J.; Ensayos de semiótica poética; Planeta; 1976.

Genette G.; "Lenguaje poético, poética del lenguaje" en Barthes R. $Y$ otros; Estructuralismo y literatura; Bs.As; Nueva Visión; 1972.

Kristeva Julia; Semiótica 1 y 2; Madrid; Fundamentos; 1981.

Talens Jenaro y otros; Elementos para una semiótica del texto artístico; Madrid; Cátedra; 1983.

\section{BIBLIOGRAFIA ESPECIFICA GENERAL}

Alonso Amado; Materia y forma en posla; Madrid; Gredos; 1955

Aguirre Raúl; Las poéticas del siglo XX; Bs.As.;ECA; 1983

Antologla de la Poesía Hispanoamericana; Selecc. Prólogo y notas de J.C.Borda; México; FCE; 1985

Bachelard Gastón; LA poética del espacio; Buenos Aires; breviarios del FCE; 65.

Bally Charles y otros; El Impresionismo en el lenguaje; Bs.As; UBA; 1956

Breton André; Manifiestos del serrealismo; Barcelona; Guadarrama; 1980

Brihuega J.; Manifiestos, Proclamas, Panfletos y Textos doctrinales-Las Vanguardias artísticas en España 1910-1931; Madrid; Cátedra.

Blanchot M.; El espacio literario; Paidós.

Carilla Emilio; ;EI vanguardismo en la Argentina; en Revista Nordeste No1; Fac. Hum.;UNNE.

Conde de Lautreamont; Obras Completas; Introducción Aldo Pellegrini; Bs.As/Barcelona; 1986

Cuadernos de Literatura No4; Instituto de Letras; Facultad de Humanidades; UNNE; Resistencia; 1988.

De Sola Graciela; Proyecciones del surrealismo en la Literatura Argentina; Bs.As.; Eca; 1967.

Duplessis Yvonne; El Surrealismo; Barcelona; Oikos-tau; 1972.

Durozoi G.; Lecherbonnier B.; El Surrealismo; Madrid; Guadarrama; 1974.

Freidemberg Daniel; La poesía del cincuenta; Bs.As.; CEAL; 1981.

Furlan luis R.; Generación poética del 50; Bs.As.; ECA; 1974.

Ghiano Juan C.; Poesía argentina del siglo XX; Méx; FCE; 1957.

Martino Pierre; Parnaso y Simbolismo; Bs.As; El Ateneo; 1948

Montaldo Graciela y colaboradores; Yrigoyen, entre Borges y Artt (1916-1930); Historia social de la literatura argentina, TVII; Bs.As; Contrapunto; 1989.

Monteleone Jorge "La noción de futuridad y la categoría de principio en la vanguardia Latinoamericana"; en cuadernos de Literatura N4; Fac. Hum.; UNNE; Rcia; 1989.

Muschietti Delfina;"Las poéticas de los 60"; en Cuadernos de Lit. N4; Fac.Hum; UNNE; Rcia; 1989.

Paz Octavio; El arco y la lira/Los signos en rotación; Méx; FCE; 1972. Los hijos del limo; Barcelona; Seix Barral; 1974.

Pellegrini Aldo; Antología de la Poesía Surrealista; Bs.As/Barcelona; Argonauta; 1981.

Porrúa Ana; traficando palabras- Poesía argentina en los márgenes; Bs.As; Libros del Quirquincho; 1990.

Prieto Adolfo; El discurso criollista en la formación de la Argentina moderna; Bs.As; Sudamericana; 1988.

Raymond Marcel; De Baudelaire al surrealismo; Méx.; FCE; 1960

Salas Horacio; Generación poéitca del 60; Bs.As; ECA; 1975. 
Sarlo Beatriz; Una modernidad periférica; Bs.As; 1920 y 1930; Bs.As; Nueva Visión; 1988. Setton Yaki; La revuelta surrealista; Bs.As; Libros del Quirquincho; 1990.

Torre G; Ultraísmo, existencialismo y objetivismo en literatura; Madrid; Guadarrama; 1968

Videla Gloria; El Ultraismo; Madrid; Gredos; 1963

Yurkievich Saúl; A través de la trama; Barcelona; Muchnik; 1984

Yurkievich Saúl;"Los avatares de la vanguardia"; en Rev. Iberoamericana No118/119, ene-jul 1982.

\section{BIBLIOGRAFIA ESPECIFICA PARTICULAR}

Madariaga francisco; Obra reunida; Méx; FCE

La balsa mariposa; Pról. de Oscar Portela, Municipalidad de la ciudad de Corrientes, 1982.

"El tren casi fluvial" en literatura y Critica; Primer Encuentro UNL; 1986.

"Criollo del Universo y otros poemas" en Los Grandes Poetas; Bs.As: CEAL No44: 1988

Poesía Argentina Contemporánea; T1; vol III; Bs. As. Fundación Argentina para la poesia; 1979.

"La urgencia del paisaje" entrevista a F. Madariaga en la Danza del Ratón, N6; dic 1984.

Cobo Borda J.G. y otros; Usos de la imaginación; Bs. As.; El Imaginero; s/f.

Kamenszain Tamara; EI texto silencioso-tradición y vanguardia en la poesía sudamericana; Méx.; UNAM; 1983.

Homenaje a Girondo;(introducción y notas Jorge Schwartz); Bs.As; Corregidor; 1987

Girondo Oliverio; Espantapájaros (al alcance de todos); Bs.As; Losada; 1991.

Oliverio Girondo; Los grandes poetas; N04; 1987.

Ricardo Molinari; Los Grandes Poetas No 41; 1988.

Páginas de Enrique Molina (seleccionadas por el autor); Bs.As; Celtia; 1983.

Enrique Molina; Los Grandes Poetas No49; Bs.As.; CEAL; 1989

Edgar Bayley; id. N051; 1989.

Raúl Gustavo Aguirre; id. No42, 1988

Veiravé Alfredo: El imperio milenario; Bs.As.; Sudamericana;1973 La màquina del mundo; Bs.As.; Sudamericana; 1976 Historia Natural; Bs.As.; Sudamericana; 1980

Radar en la tormenta; Bs.As; Sudamericana; 1985 Laboratorio Central; Bs.As. Sudamericana; 1992.

Alvarenga Martín; Drogados por la luz; Bs.As; Lohlé; 1974 Cantando como si naciera; Bs.As; Eco Contemporáneo; 1984

Portela Oscar; Había una vez; Bs.As; Botella al mar, 1983 Memorial de Corrientes; Bs.As;Tiempo; 1985

Ibánez Iris; "Mediodía en un remate de hacienda"; dic. 1980.

Portela Oscar; "El resplandor de la gracia poética"; febrero 1986.

Pérez de Medina Elena; "Francisco Madariaga: un modo de habitar proféticamente" Trabajo leido en Jornadas sobre la literatura argentina del litoral; Posadas, 25/8/83.

Vasco Juan Antonio: "un chasqui de guerra celeste y otro colorado": prólogo a Francisco Madariaga; Poemas; Col Cuadernos de Difusión No77; Caracas, Ed. Arte.

"Francisco Madariaga. La poesía como ofocio de magia terrestre" en Revista Tiempo, Ctes, nov. 1976

Francisco Madariaga: POESIA Y PAIS. COMARCA, PAISAJE, HISTORIA. Ponencia leída en el III Encuentro Nacional de Escritores; Ctes, 23 al 25 ago 1991. 